\title{
EXPERIMENTAL INVESTIGATIONS ON AIR COOLED DIESEL ENGINE USING RUBBER SEED BIODIESEL AND ITS BLENDS AS A SUBSTITUTE FUEL FOR PETRO-DIESEL
}

\author{
Anjaneya G ${ }^{1}$, Prabhakar Reddy $C^{2}$, Udaya Ravi $M^{3}$, Sunil $S^{4}$ \\ ${ }^{1}$ Assistant Professor, Mechanical Engineering, RVCE, Bengaluru, Karnataka, India \\ ${ }^{2}$ Professor and Principal, SVCE, Bengaluru, Karnataka, India \\ ${ }^{3}$ Associate Professor, Mechanical Engineering, SVCE, Bengaluru, Karnataka, India \\ ${ }^{4}$ Assistant Professor, Mechanical Engineering, SVCE, Bengaluru, Karnataka, India
}

\begin{abstract}
Experiments were conducted on a Kirloskar make, air cooled diesel engine using rubber seed biodiesel and its blends with diesel $(10 \%, 20 \%$, and $30 \%$ by volume) as a substitute fuel to petro- diesel. The load was applied in the range 0 to 100\% (0, 25\%, 50\%, $75 \%$ and $100 \%$ ) in steps of $25 \%$ of maximum load at an injection pressure of 200 bar and injection timing of $23^{\circ}$ of crank angle before top dead centre. The performance parameters (BP, BTE and BSFC), pollutants $\left(\mathrm{CO}, \mathrm{HC}, \mathrm{CO}_{2}, \mathrm{NO}_{x}\right.$ and smoke opacity) and combustion characteristics (cylinder pressure rise and heat release rate for every degree of crank angle) were measured for pure biodiesel and its blends. The results obtained were compared with petro-diesel. Among the fuels tested, $10 \%$ blend of rubber seed biodiesel showed a better performance in terms of increased Brake Thermal Efficiency (BTE) and decreased Brake Specific Fuel Consumption (BSFC). Significant reductions in pollutants (except $N O_{x}$ ) were observed for pure rubber seed biodiesel and its blends at all power outputs as compared to petro-diesel. Combustion features of rubber seed biodiesel and its blends were similar to petro-diesel operation.
\end{abstract}

Key words: Biodiesel, Blends, Injection pressure, Performance, Emissions, Combustion characteristics

\section{INTRODUCTION}

Petroleum based fuels are depleting at faster rate because of their demand in all the fields such as transportation, agriculture, power generation, etc., in India as well as other countries. There should be an alternate to diesel fuel may be after a decade or two, when scarcity exists for diesel in all over the world. As $100 \%$ replacement cannot be possible due to the problems associated with hardware components of internal combustion engines, but there is a provision to replace $20-30 \%$ of diesel with an alternate fuel in an existing engine without any modifications [1]. Since the invention of internal combustion engine, many researchers tried usage of alternative fuel, but there are still many hindrances in commercializing the usage of alternative fuel in many countries [2].

Bio-fuels (vegetable oils) are considered as a choice for alternative to diesel because of their similar physical and chemical properties as that of conventional diesel [3, 4]. Bio fuels obtained from tree borne seeds or animal fats cannot be used directly in the engine because of their higher viscosity (almost ten times more than conventional diesel) [5]. This high viscosity of oil leads the problems of flow through the lines from tank to the injector, results in wear and tear of fuel injector parts, premature wear of the injection pump, carbon deposits inside the engine cylinder and crown of the piston, combustion chamber, valve seats etc. thereby decreasing the engine life $[4,5]$. Other problems of high viscosity are poor atomization, improper mixing with air in the combustion chamber, partial combustion, dilution with lubricating oil. These problems results in lower power output from the engine. The one possible solution to overcome these problems i.e., to reduce the viscosity of straight vegetable oil and make it nearer to diesel is, to convert it in to biodiesel by a well known simple chemical process called transesterification $[3,6]$.

Transesterification is a process in which vegetable oil reacts with a methanol or ethanol in the presence of a catalyst to produce biodiesel and glycerol as a byproduct. Biodiesel is having almost same properties as that of conventional diesel and can be successfully used in engine either directly or in blended form. Some properties of biodiesel are superior to diesel such as higher cetane number, least sulphur content and presence of $10-12 \%$ of oxygen by weight $[3,7]$. Higher cetane number indicates better ignition quality of biodiesel; lower sulphur content reduces $\mathrm{SO}_{2}$ emissions and presence of oxygen results in complete combustion. Engine running with biodiesel and its blend reduces harmful exhaust emissions such as $\mathrm{CO}$, UBHC, smoke and particulate matters as compared to conventional diesel [8]. The $\mathrm{CO}_{2}$ emission by biodiesel is balanced on the earth as $\mathrm{CO}_{2}$ will be absorbed by trees and reducing global warming. The NOx emission by biodiesel is more compared to conventional diesel [2]. NOx emission can be reduced using a catalytic converter in the exhaust pipe or using exhaust gas recirculation technique [9].Rubber seed biodiesel is 
identified as one of the potential substitute fuel to diesel in the present research work from the literature survey made $[10,11,12]$.

\section{BIODIESEL PRODUCTION}

The ripened seeds of rubber tree are collected and dried in sunlight and decorticated, to separate shell and seeds in a decorticator. The seeds are crushed for oil in an oil expeller. The crude rubber seed oil is then filtered to remove impurities. The filtered crude oil is transesterified to obtain biodiesel. Transesterification is a chemical reaction between oil and (methyl or ethyl) alcohol to form mono esters and glycerol. In order to improve the reaction rate and yield, a catalyst is generally used. The oil to be transesterified is pretreated to remove impurities and moisture content present in crude oil. The moisture content in oil is removed by heating the oil above $100^{\circ} \mathrm{C}$. Then the oil is titrated to determine the amount of FFA (Free Fatty Acid) present in it. This determines the quantity of catalyst to be added for the reaction. Generally catalyst is added along with alcohol (methanol or ethanol) to the oil. The chemical reaction takes place at prescribed temperature for definite amount of time. The glycerin and ester gets separated. The ester is washed and dried to obtain biodiesel. The block diagram of the trasnesterification and chemical process of conversion is as shown in Fig 1 (a) \& (b). Properties of rubber seed biodiesel and its blends compared to petro-diesel are given in table 1 .

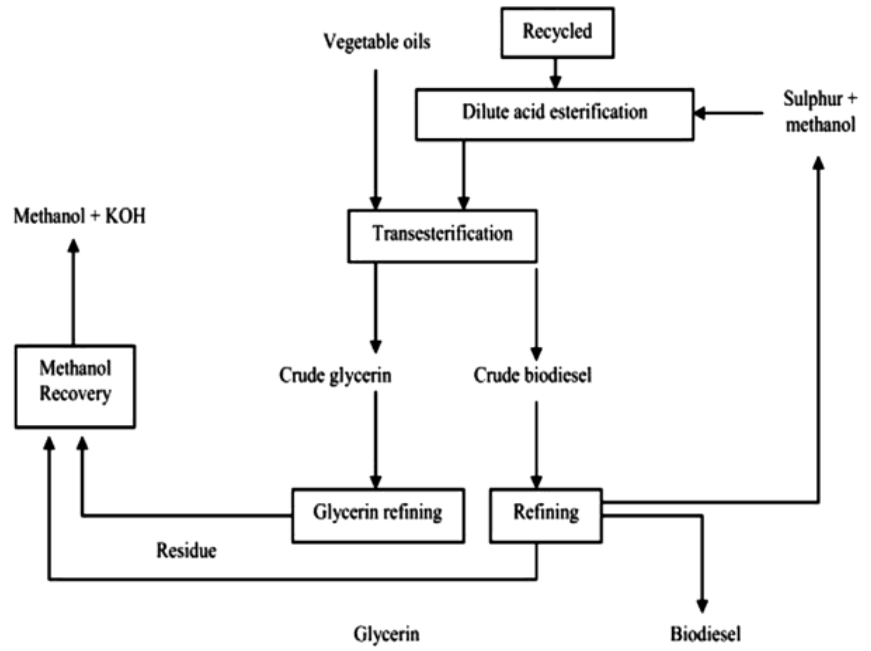

Fig. 1 (a) Block diagram of transesterification

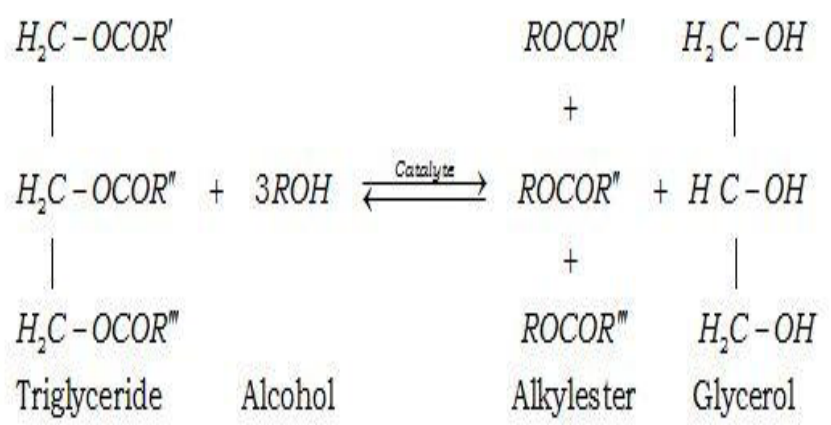

Fig. 1 (b) Chemical reaction of transesterification process
Table 1- Properties of Rubber seed biodiesel and its blends compared with petro-diesel

\begin{tabular}{clcccc}
\hline $\begin{array}{c}\text { Sl. } \\
\text { No. }\end{array}$ & Fuel & $\begin{array}{c}\text { Kinematic } \\
\text { viscosity } \\
\text { @ 40 } \mathbf{C} \\
(\mathbf{C s t})\end{array}$ & $\begin{array}{c}\text { Flash } \\
\left.\text { point } \mathbf{(}^{\mathbf{0}} \mathbf{C}\right)\end{array}$ & $\begin{array}{c}\text { Density } \\
\left(\mathbf{k g} / \mathbf{m}^{\mathbf{3}}\right)\end{array}$ & $\begin{array}{c}\mathbf{C V} \\
(\mathbf{k J} / \mathbf{k g})\end{array}$ \\
\hline 1 & Diesel & 2.54 & 54 & 840 & 42500 \\
2 & RSBD10 & 2.81 & 63 & 843 & 40810 \\
3 & RSBD20 & 3.24 & 67 & 847 & 39771 \\
4 & RSBD30 & 3.73 & 71 & 850 & 39232 \\
& $\begin{array}{l}\text { RSBD100 } \\
\text { (Pure } \\
\text { biodiesel) }\end{array}$ & 5.81 & 146 & 874 & 34662 \\
\hline
\end{tabular}

\section{EXPERIMENTAL SET UP AND PROCEDURE}

The engine used for conducting experiments was a Kirloskar make, air cooled, single cylinder, four stroke diesel engine used for agriculture/generator set applications. The engine was coupled with a swinging field dynamometer for motoring the engine as well applying the load through electric rheostat system. Fuel consumption rate was measured using a burette and measuring the time taken to consume $10 \mathrm{cc}$ of fuel. The air flow rate was measured by an air box fitted with sharp edge orifice meter connected to Utube manometer which gives reading in meters of water column and which is converted to meters of air column. The water inlet \& outlet temperatures, exhaust gas inlet \& outlet temperatures were recorded using thermocouples through digital indicators of date acquisition panel of the engine. The pollutants - $\mathrm{CO}, \mathrm{CO}_{2}$ were noted in percentage volume, where as $\mathrm{NO}_{\mathrm{x}}$ and $\mathrm{HC}$ were noted in ppm volume by five gas analyzer (AVL DI GAS 444). Smoke emission was measured in percentage of smoke opacity by Smoke Meter (AVL 415). The angle encoder (AVL 365 C) was mounted at the shaft between engine and dynamometer to record the position of crank during its rotation with respect to top dead centre. The pressure transducer was incorporated in cylinder head to record the variation of pressure for every degree of crank rotation. Plot of pressure variation and the heat release rate with crank angle, pressure variation with cylinder volume, cumulative heat release rate were recorded through data acquisition system interfaced with Software (AVL INDICOM V 2.5). The engine set up is shown in Fig.2 and its specifications are given in table 2 .

Initially experiments were conducted from 0 to $100 \%$ load, applying load in steps of $25 \%$ of rated load $(0,25 \%, 50 \%$, $75 \%$, and $100 \%$ ) with petro-diesel in order to get baseline data. Then engine was made to run with rubber seed biodiesel and its blends (10\%, $20 \%$ and $30 \%$ by volume) by applying the loads as mentioned above. The water flow rate was adjusted to ensure effective cooling of the engine components. The voltage and current readings were noted by applying electric loading to the engine by switching on rheostat. Performance parameters such as BP, BTE, BSFC etc. were computed for biodiesel and its blends and results 
were compared with petro-diesel. Pollutants $(\mathrm{CO}, \mathrm{CO} 2$, $\mathrm{NO}_{x}$, and $\mathrm{HC}$ ) were noted using gas analyzer and smoke opacity (in percentage) was measured using smoke meter and values are compared with petro-diesel. From the data acquisition system cylinder pressure rise and heat release rate with reference to crank angle position was extracted and plots were drawn. The exhaust emissions and combustion characteristics were compared with that of petro-diesel results

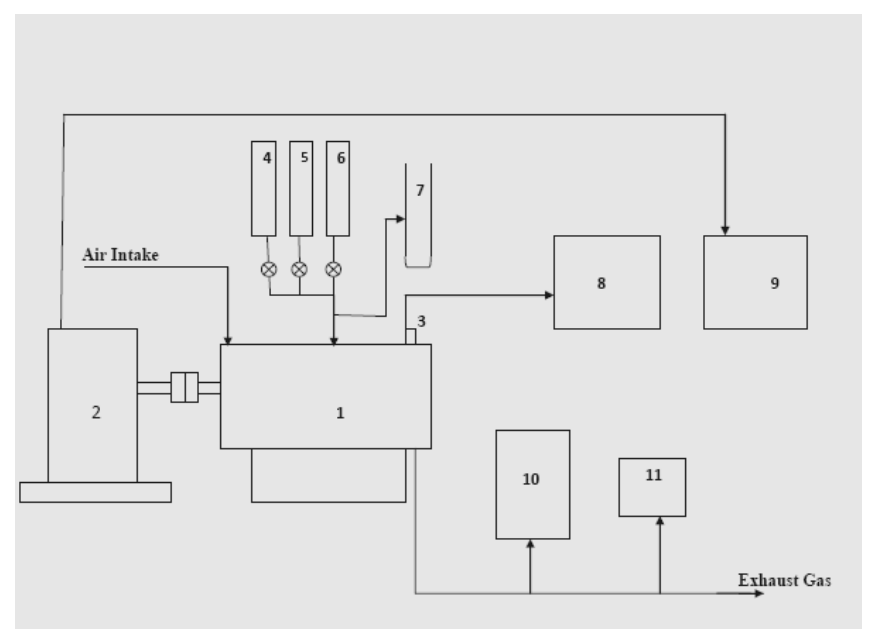

1. Test Engine 2. Swinging field dynamometer 3. Pressure sensor 4. Diesel tank 5. Biodiesel tank

6.Biodiesel-diesel blends tank 7. Burette 8. Data acquisition system 9. Dynamometer controller

10. AVL DI Gas analyzer 12. AVL Smoke meter

Fig. 2 Test engine setup

Table 2. Test engine specifications

Make:- Kirloskar Oil engine, Single cylinder, four stroke (TAF1)

\begin{tabular}{ll}
\hline Rated power & $4.4 \mathrm{~kW}(6 \mathrm{HP})$ \\
Rated speed & $1500 \mathrm{rpm}$ \\
Bore x Stroke & $87.5 \mathrm{~mm} \times 110 \mathrm{~mm}$ \\
Compression ratio & $17.5: 1$ \\
Cubic capacity & $0.662 \mathrm{ltr}$ \\
Injection timing & $23^{0} \mathrm{bTDC}$ \\
Nozzle opening pressure & $200 \mathrm{bar}$ \\
Piston bowl & Hemi spherical \\
\hline
\end{tabular}

Dynamometer specification

Swinging Field dynamometer (Make-power stars)

KVA-5, PH-1, V-240 Volts, I-21 Amps, RPM-1500

\section{RESULTS AND DISCUSSIONS}

4.1 Brake Thermal Efficiency: - The plot of variation of BTE with power output (Brake Power) is shown in Fig.5 for petro-diesel, biodiesel and its blends. BTE is an indication of conversion of chemical energy of fuel due to combustion in to useful mechanical energy output. The brake thermal efficiency of D, RSBD10, RSBD20, RSBD30 and RSBD100 is $27.88 \%, 29.245 \%, 27.47 \%, 27.854 \%$ \&
$26.54 \%$ respectively at $3.3 \mathrm{~kW}$ of power output. Percentage increase in BTE for RSBD10 is approximately 5\% as compared to petro-diesel. The BTE of rubber seed biodiesel and other blends is a little lower than diesel at all output powers. As the concentration of biodiesel in the blend increases, viscosity and density of the blend increases and this results in poor atomization, poor mixing and incomplete combustion, thereby decreasing BTE. The increase in BTE of RSBD10 may be because of improved combustion of the mix compared to petro-diesel owing to the presence of small percentage of oxygen molecule in the biodiesel and approximately the same chemical properties as that of petrodiesel due to lower concentration of biodiesel in the blend.

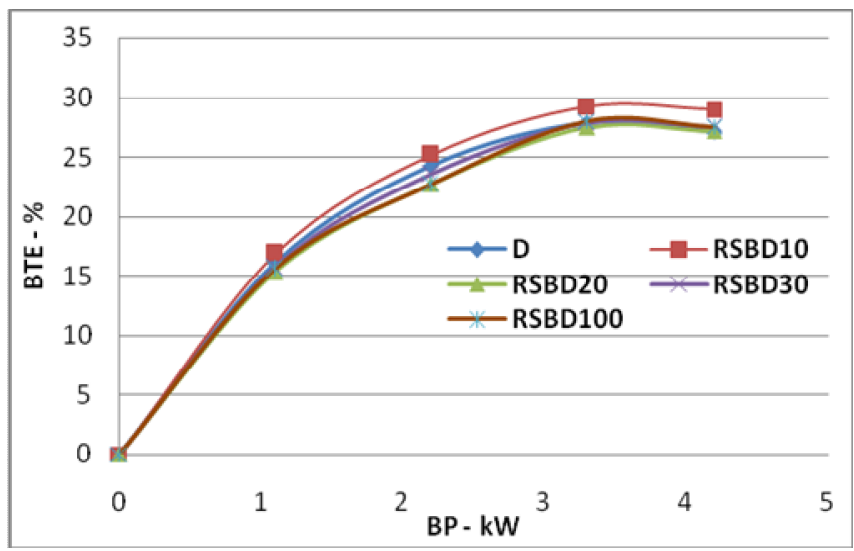

Fig 5. Variation of BTE with brake power

4.2 Brake Specific Fuel Consumption: - The plot of variation of BSFC with brake power is shown in Fig.6 for petro-diesel, biodiesel and its blends. BSFC indicates one $\mathrm{kg}$ of fuel burnt to produce one $\mathrm{kW}$ of power in one hour As heating value of rubber seed biodiesel is approximately $18 \%$ less than the pure diesel, BSFC of rubber seed biodiesel and its blends (except RSBD10) is more for all output powers as compared to petro-diesel. The reason for increase in brake specific fuel consumption is higher viscosity, higher density and lower heating value of biodiesel compared to petrodiesel. Because of lower hating value, more fuel quantity is to be supplied in to the combustion chamber in a given interval of time to produce the required brake power for an applied load, hence BSFC increases. For RSBD10, decrease in BSFC may be the presence of oxygen in ester form in the biodiesel and lower percentage of biodiesel (only 10\%) in the blend, resulting in similar pattern of droplet sizes and cone angle of injection as that of diesel ensures complete combustion. The values of SFC at $3.3 \mathrm{~kW}$ of power output for D, RSBD10, RSBD20, RSBD30 and RSBD100 are $0.3109, \quad 0.2973,0.3184,0.3195$ and $0.3372 \mathrm{~kg} / \mathrm{kW}-\mathrm{h}$ respectively. Percentage decrease in BSFC for RSBD10 is $4.37 \%$ and percentage increase in BSFC is $2.4 \%, 2.78 \%$ and $8.45 \%$ for RSBD20, RSBD30 and RSBD100 respectively compared to petro-diesel. 


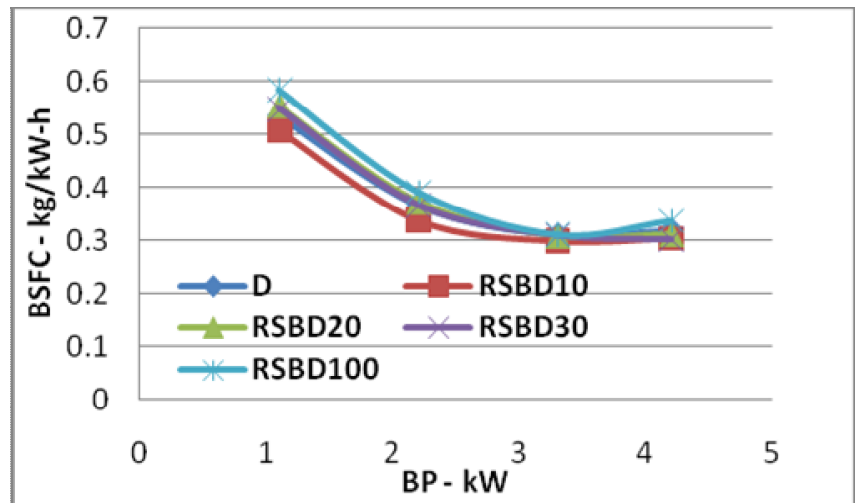

Fig 6. Variation of BSFC with brake power

3 Carbon Monoxide (CO) Emission: - The plot of variation of $\mathrm{CO}$ emissions with brake power is shown in Fig.7 for petro-diesel, rubber seed biodiesel and its blends. The Formation of $\mathrm{CO}$ indicates partial/incomplete combustion of fuel. The trend of $\mathrm{CO}$ emission is similar for all the fuels tested. Among the fuels tested $\mathrm{CO}$ emissions are higher for petro-diesel at all power outputs compared to rubber seed biodiesel and blends. As the percentage of biodiesel in the blend increases the $\mathrm{CO}$ emission decreases and it is lowest for rubber seed biodiesel. Reduction of $\mathrm{CO}$ emission is a sign of better burning of the fuel. As biodiesel is an oxygenated fuel, this helps in better combustion and results in less $\mathrm{CO}$ formation. At an instance percentage decrease in CO emission for RSBD10, RSBD20, RSBD30 and RSBD100 are $22 \%, 33 \%, 44 \%$ and $66 \%$ respectively at full load (4.2 $\mathrm{kW})$ compared to petro-diesel.

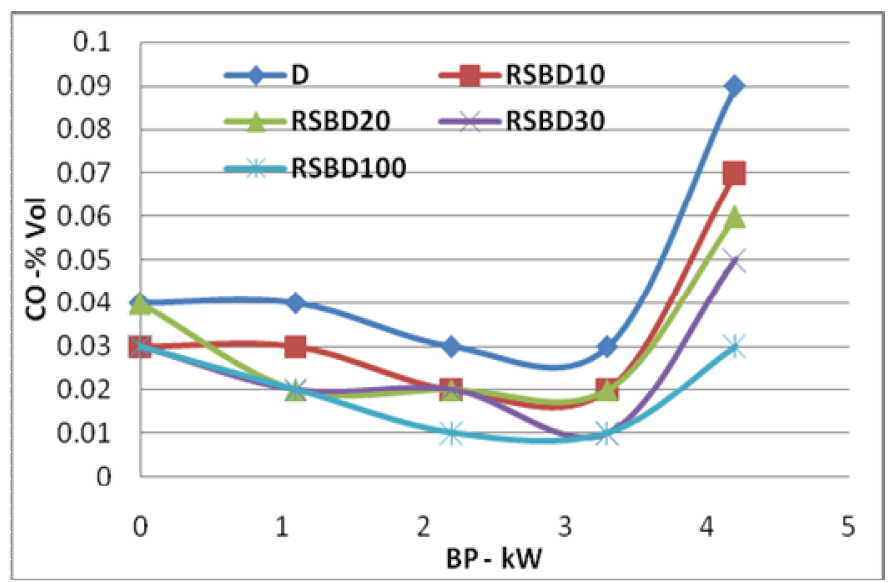

Fig.7 Variation of $\mathrm{CO}$ with brake power

4.4 Hydro Carbon (HC) Emission: - The plot of HC emissions variation with brake power is shown in Fig. 8 for petro-diesel, rubber seed biodiesel and its blends. As observed from plot, emission of $\mathrm{HC}$ increases with increase in power output for all the fuels tested. As the blend percentage increases, $\mathrm{HC}$ emission decreases. $\mathrm{HC}$ emissions are lower for pure rubber seed biodiesel and its blend as compared to petro-diesel. In spite of higher viscosity of pure biodiesel it burns effectively and completely (from no load to full load) due to the presence of oxygen molecule and having lower carbon percent compared to petro-diesel, thereby reducing $\mathrm{HC}$ emissions. The percentage decrease in HC emissions for RSBD10, RSBD20, RSBD30 and
RSBD100 are $17.24 \%, 37.93 \%, 48.27 \%$ and $58.62 \%$ respectively compared to diesel at $3.3 \mathrm{~kW}$ of power output.

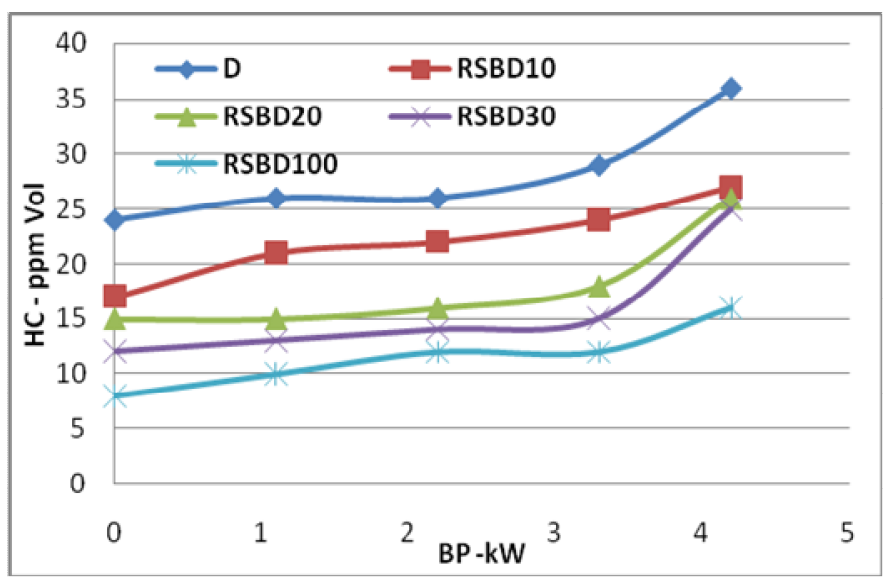

Fig 8. variation of $\mathrm{HC}$ emission with brake power

4.5 Carbon Dioxide (CO2) Emission: - The plot of $\mathrm{CO}_{2}$ variation with power output is shown in Fig.9 for petrodiesel, rubber seed biodiesel and its blends. The $\mathrm{CO}_{2}$ emission increases as brake power increases for all the fuels tested.

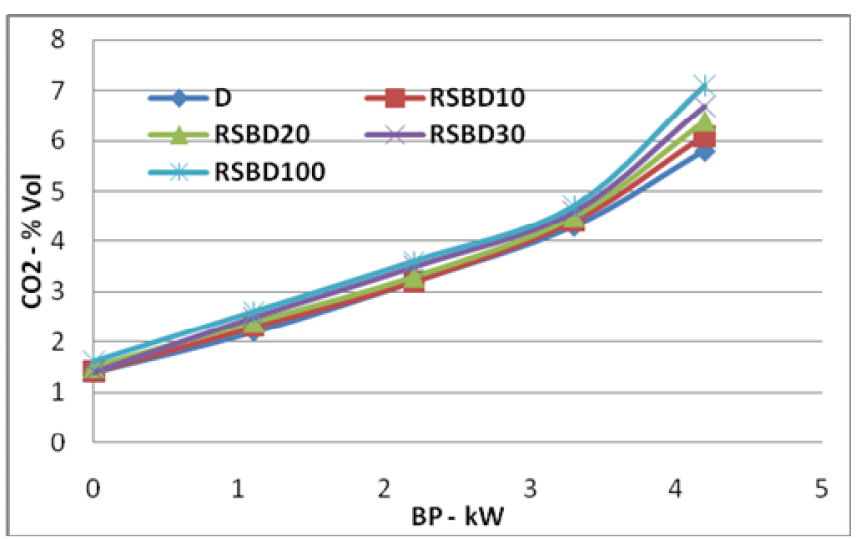

Fig 9. Variation of $\mathrm{CO}_{2}$ with brake power

The $\mathrm{CO}_{2}$ emission is more for biodiesel and its blends as compared to petro-diesel at all power outputs. It clearly indicates that biodiesel and its blends undergo complete combustion. The percentage increase in $\mathrm{CO}_{2}$ emission for RSBD10, RSBD20, RSBD30 and RSBD100 are 30.3\%, $33.3 \%, 36.6 \%$ and $45.45 \%$ respectively compared to diesel at $3.3 \mathrm{~kW}$ of power output. Even $\mathrm{CO}_{2}$ emission increases with biodiesel; this will be balanced as the plants absorb the same and reduce global warming.

4.6 Smoke Opacity: - The plot of variation of percentage of smoke opacity with power output is shown in Fig.10 for petro-diesel, rubber seed biodiesel and its blends. Higher percentage of smoke opacity indicates more HC emissions, due to incomplete combustion of the fuel. Smoke opacity of all the fuels tested increases by increase in brake power. Smoke opacity is lower for rubber seed biodiesel and blends compared to petro-diesel at all power outputs due to better combustion. Percentage decrease in smoke opacity for RSBD10, RSBD20, RSBD30 and RSBD100 are 20.72\%, 
$40 \%, 43.86 \%$ and $50 \%$ respectively compared to diesel at $3.3 \mathrm{~kW}$ of power output.

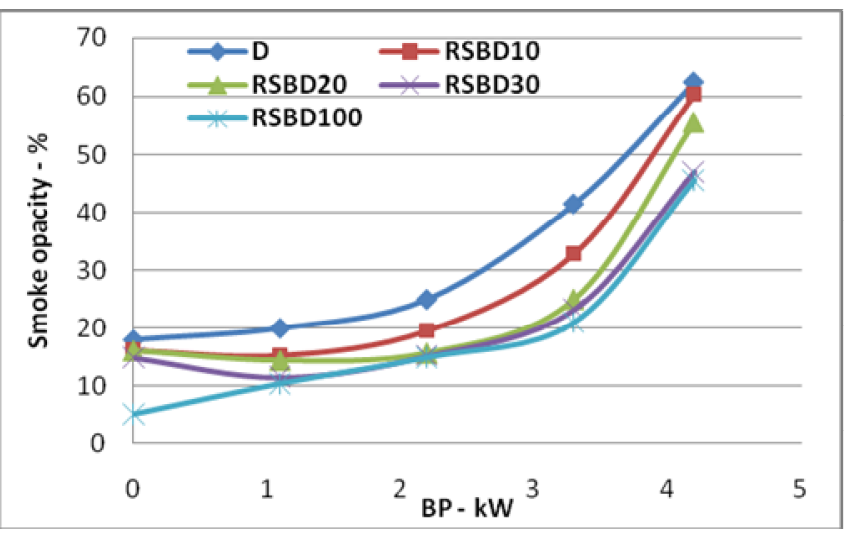

Fig 10. Variation of percentage of smoke opacity with brake power

4.7 Oxides of Nitrogen (NOx):- The plot of variation of $\mathrm{NO}_{\mathrm{x}}$ emission with power output is shown in Fig.11 for petro-diesel, rubber seed biodiesel and its blends. The $\mathrm{NO}_{\mathrm{x}}$ emission increases for all the fuels tested as the brake power increases. The percentage increase in $\mathrm{NO}_{\mathrm{x}}$ is high for rubber seed biodiesel and blends compared to petro-diesel. The higher NOx emission from rubber seed biodiesel and its blends is due to the presence of small amount of oxygen in the biodiesel which effectively takes part into burning resulting combustion to happen nearest to stiochiometric condition, which increases temperature of exhaust gases and gives room for $\mathrm{NO}_{\mathrm{x}}$ formation. The percentage increase in $\mathrm{NO}_{\mathrm{x}}$ for RSBD10, RSBD20, RSBD30 and RSBD100 are $5.47 \%, 8.71 \%, 20.78$ and $25 \%$ respectively at $3.3 \mathrm{~kW}$ of power output compared to diesel.

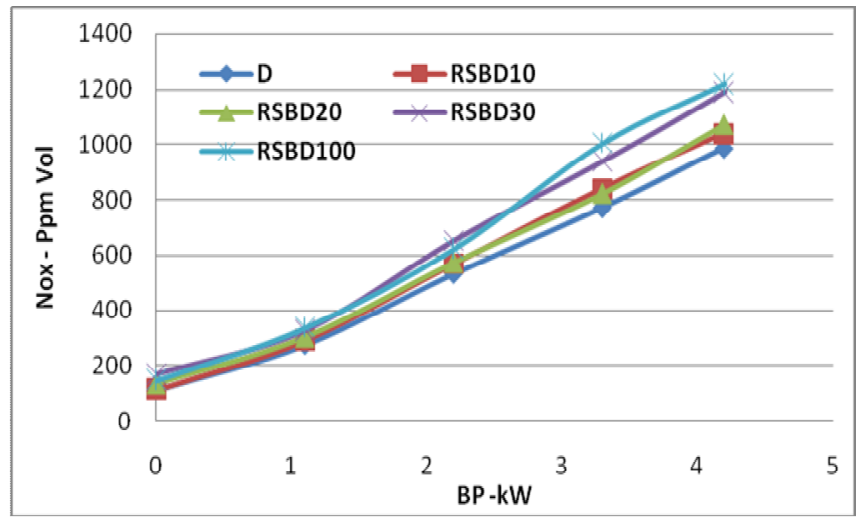

Fig. 11 the variation of $\mathrm{NO}_{\mathrm{x}}$ with brake power

4.8 Exhaust Gas Temperature (EGT):- The plot of variation of EGT with power output is shown in Fig.12 for petro-diesel, rubber seed biodiesel and its blends. Temperature of exhaust gases increases for all the fuels tested as power output increases. EGT is higher for rubber seed bio diesel and its blends due to complete combustion. Increase in EGT is more for pure biodiesel of rubber seed at all power outputs and which is indicated by more $\mathrm{NO}_{\mathrm{x}}$ emission. The percentage increase in EGT for RSBD10, RSBD20, RSBD30 and RSBD100 are $1.67 \%, 4.28 \%, 10 \%$ and $20 \%$ respectively compared to diesel at $3.3 \mathrm{~kW}$ of power output.

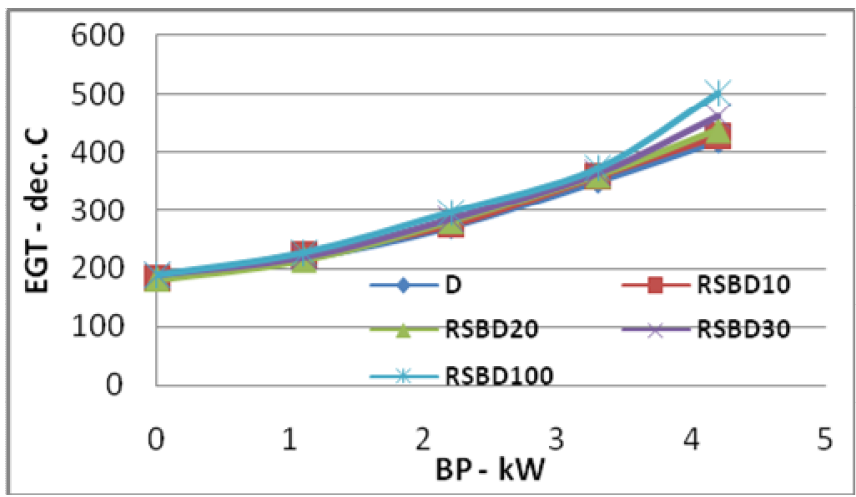

Fig 12. Variation of EGT with brake power

4.8 Cylinder pressure:- The plot cylinder pressure variation with Crank Angle (CA) measured in degrees is shown in Fig. 13 for petro-diesel, rubber seed biodiesel and its blends at $3.3 \mathrm{~kW}$ of power output. The pressure increases from $0 \%$ to $100 \%$ load for all the fuels tested and cylinder peak pressure is at about $6-10^{\circ}$ of CA after top dead centre. The trend of peak pressure rise for rubber seed biodiesel and blends is similar to petro-diesel. This is an indication of similar combustion characteristics of rubber seed biodiesel and blends as compared to petro-diesel.

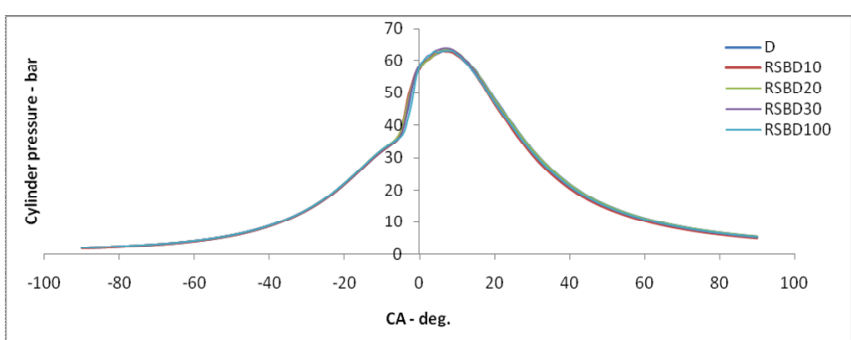

Fig.13 Variation of cylinder pressure with crank angle measured in degrees

4.9 Heat release rate:- The plot of heat release rate variation with crank angle measured in degrees is shown in Fig. 14 for petro-diesel, rubber seed biodiesel and its blends at $3.3 \mathrm{~kW}$ of power output As observed from the graph heat release rate is higher for petro-diesel and RSBD10 compared to rubber seed biodiesel and other blends (RSBD20, RSBD30). The peak heat release rate is nearer to top dead centre for diesel, where as it is before top dead centre for rubber seed biodiesel and its blends. The delay period is reduced during preparation (physical delay + chemical delay) stage for rubber seed biodiesel and its blends

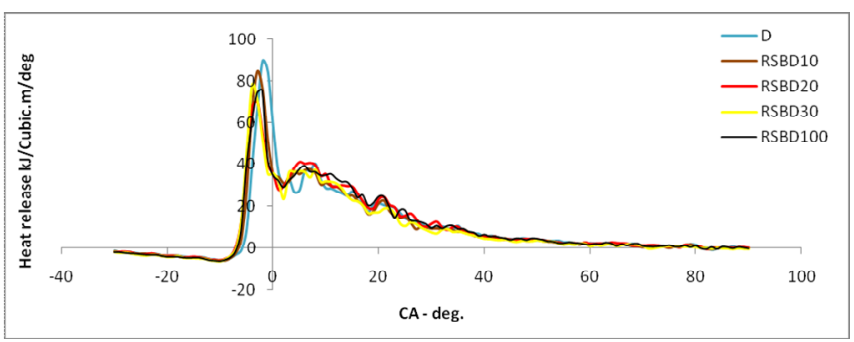


Fig. 14 Variation of heat release rate with crank angle in degrees

\section{CONCLUSIONS}

In the present investigation experiments were conducted on a Kirloskar make, air cooled diesel engine using Petrodiesel, rubber seed biodiesel and its blend at differ load conditions (power outputs) at an nozzle opening pressure of 180 bar and fuel injection timing of $23^{\circ}$ of crank angle before top dead centre. The effect of performance parameters, exhaust emissions and combustion characteristics were discussed for rubber seed biodiesel and its blends and were compared with petro-diesel. The conclusions are drawn as below.

1. The brake thermal efficiency of RSBD10 was improved by $5 \%$ at $3.3 \mathrm{~kW}$ of power output as compared to petrodiesel. For rubber seed biodiesel and its blends, brake thermal efficiency was slightly reduced at all power outputs compared petro-diesel.

2. Brake specific fuel consumption was high for rubber seed biodiesel and its blends (except for RSBD10) as compared to diesel for all power outputs. The percentage decrease in BSFC for RSBD10 is $4.37 \%$ as compared to diesel at $3.7 \mathrm{~kW}$ of power output. The same was reflected by increased BTE of RSBD10 compared to petro-diesel. Because of higher cetane number as compared to petro-diesel and hence an early heat release occurs. The after burning trend is similar for all the fuels tested.

3. Exhaust emissions ( $\mathrm{CO}, \mathrm{HC}$ and smoke opacity) were significantly improved for rubber seed biodiesel and its blends at all power outputs compared to petro-diesel.

4. Exhaust Gas Temperature were higher for rubber seed biodiesel and its blends at all power outputs as compared to petro-diesel.

5. $\mathrm{NO}_{\mathrm{x}}$ emissions were higher for rubber seed biodiesel and its blends compared to petro-diesel.

6. The combustion characteristics (cylinder pressure rise and heat release rate) of rubber seed biodiesel and its blends were similar to that of petro-diesel.

7. Rubber seed biodiesel and its blends can be successfully used in a conventional diesel engine without any hardware modifications of the basic engine with an appropriate technique of controlling exhaust NOx emissions.

As the energy demand is increasing in a day to day life and at the same time the government is imposing stringent emission norms to control air pollution, the rubber seed biodiesel could be one of the potential substitutes for a conventional diesel in future years.

\section{REFFERENCES}

[1] Labeckas, G, Slavinskas, S: The effect of rapeseed oil methyl ester on direct injection diesel engine performance and exhaust emissions. Energ. Convers. Manage. 2006, 47(13-14), 1954-1967

[2] Hugo, HV, Patricio, GVD, Armando, G, Héctor, P: The development impact of biodiesel: a review of biodiesel production in Mexico. Int. J. Energ. Environ.Eng. 2, 91-99 (2011)

[3] Hoekman SK, Broch A, Robbins C, Ceniceros E, Natarajan M. Review of biodiesel composition, properties, and specifications. Renew Sust Energy Rev 2012;16:143-69.

[4] Singh SP, Singh D: Biodiesel production through the use of different sources and characterization of oils and their esters as the substitute of diesel: a review. Renew Sust Energ Rev 2010, 14(1):200-216.

[5] Recep Altõn, Selim Cß etinkaya , H useyin Serdar, Yucesu, The potential of using vegetable oil fuels as fuel for diesel engines. Energy Conversion and Management 2001, 42, 529-538

[6] Raja S.A., Smart D.S.R. and Lee C.L.R., Biodiesel production from jatropha oil and its characterization, Research Journal of Chemical Sciences, (2013)1(1),8187

[7] M. Lapuerta, O. Armas, and J. RodríguezFernández,"Effect of biodiesel fuels on diesel engine emissions,"Progress in Energy and Combustion Science, vol. 34, no. 2, pp. 198-223, Apr. 2008Ramadhas AS, Jayaraj S, Muraleedharan C. Biodiesel production from high FFA rubber seed oil. Fuel 2005;84:335-40.

[8] B. Tesfa, R. Mishra, F. Gu, and N. Powles, "Prediction models for density and viscosity of biodiesel and their effects on fuel supply system in CI engines," Renewable Energy, Dec. 2010,vol. 35, no. 12, pp. 2752-2760,.

[9] S. M Palash M.A.Kalam,H.H.Masjuki,B.M.Masum,I.M.RizwanulFa ttah,M.Mofijur. Impacts of biodiesel combustion on NOx emissions and their reduction approaches. Renewableand Sustainable Energy Reviews 23 (2013) 473-490

[10] Morshed M, Ferdous K, Khan MR, Mazumder MSI, Islam MA, Uddin MT. Rubber seed oil as a potential source for biodiesel production in Bangladesh. Fuel 2011;90:2981-86.

[11] Yang R, Su M, Zhang J, Jin F, Zha C, Li M, et al. Biodiesel production from rubber seed oil using poly (sodium acrylate) supporting $\mathrm{NaOH}$ as a water-resistant catalyst. BioresourTechnol 2011;102:2665-71.

[12] Ng WPQ, Lam HL, Yusup S. Supply network synthesis on rubber seed oil utilisation as potential biofuel feedstock. Energy 2013;55:82-8. 


\section{BIOGRAPHIES}

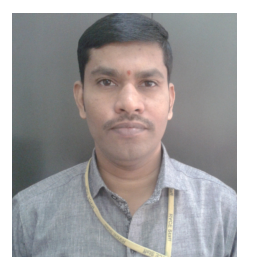

Mr. Anjaneya G. completed his B.E. Mechanical from VEC Bellary and his Masters in Thermal science and engineering from UVCE, Bengaluru. He is having 15 years of teaching and five years of research experience. Currently he is working as Assistant professor in RVCE, Bengaluru. His areas of research are biofuesl and IC engines.

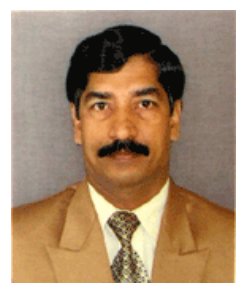

Dr. C. Prabhakar Reddy working as Principal in SVCE, Bengaluru, has a career spanning over two decades in the field of Engineering education. Starting as a Lecturer in 1980, after completing his Masters with Distinction, he acquired a Doctorate on I.C. Engines in 1995 in a record time of 31/2 years from R. E. C. Warangal (A.P.). He is one of the youngest academic senate member for VTU under which 122 Engg colleges operates and one of the key member involved in decision making about the various activates of the VTU. He has published 63 Technical Papers in National / International Conferences/ Seminars / Journals in the last 5 years. $\mathrm{He}$ is at present guiding 4 students pursuing the Doctoral Program of JNTU (Hyderabad) and Visvesvaraya Technological University, Belgaum. He is also a Co-coordinator, responsible for preparing and getting sanctioned three MODROBS projects under AICTE scheme at Vijayanagar Engineering College, Bellary. 